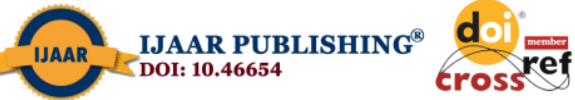

International Journal of Advanced Academic Research (Social and Management Sciences) | ISSN: 2488-9849

Vol. 6, Issue 11 (November, 2020) |www.ijaar.org

Journal DOI: 10.46654/ij.24889849

Article DOI: 10.46654/ij.24889849.s6121011

\title{
WORKPLACE BEHAVIOUR AND ORGANIZATIONAL EFFICACY OF FAST FOOD RESTAURANTS IN PORT HARCOURT, RIVERS STATE
}

\author{
Anyanwu, Obinna Elvis \\ Department of Management, Faculty of Business Studies, \\ Ignatius Ajuru University of Education, Port Harcourt, Rivers State. \\ Anyanwu44@gmail.com
}

\begin{abstract}
This study examined workplace behaviour and organizational efficacy of fast food restaurants in Port Harcourt, Rivers state. Questionnaires were distributed to 384 fast-food restaurant workers in various fast-food outlets. Results showed that $12.5 \%$ gave a poor rating of organizational performance, $31.51 \%$ gave an average rating while $55.99 \%$ gave a very good rating of organizational performance. The study also revealed that that $40.89 \%$ were satisfied with their jobs while $59.11 \%$ were not satisfied with their jobs. The analysis of organizational motivational rating shows that $16.67 \%$ opined that the organizational motivational rating was poor, $60.42 \%$ noted that the organizational motivational rating was on the average while $22.92 \%$ of the respondents had 'very good' motivation.The findings of this study revealed statistically significant relationship between employee work behaviour and organizational efficacy ( $p$ value $0.012)$ at $95 \%(p \leq 0.05)$ probability level. However, the relationship between gender and employee work revealed no statistically significant relationship (0.571) at 95\% ( $p \leq 0.05)$ probability level.The study recommended adequate motivation of employees so as to boost organizational efficacy and performance.
\end{abstract}

Keywords: Workplace Behaviour, Organizational Efficacy, Motivational Rating, Fast Food 


\section{Introduction}

Human behaviour is greatly influenced by culture, morals, societal norms and ethics. This explains why different people respond differently to similar situations (Cascio, 2013). In any organization, a deep understanding of behavioural tendencies of employees' have become imperative as it greatly impacts organization performance However, behaviour is dynamic and sometimes in response to certain working situations. This invariably means that employee work behaviour is a factor of the work environment (Porath \& Pearson, 2009).

In recent times, the ever dynamic business environment has made businesses to become more innovative and adaptive to the changing times in order to maintain a competitive edge (Yuan \& Woodman, 2010). Employees have now become the most vital components of any thriving business. The work attributes of employees are among the reasons for businesses to stay competitive. Moreso, their innovativeness contributes significantly to the efficacy of the business (Barney, 2011).

Fast food restaurants is a business that provides cooked foods, normally packaged and kept hot for customers who either eat in the restaurants or purchase in take-away packs. In most cases, these foods are mostly cooked from a central location and distributed to the various outlets to ensure conformity to standards (Mustapha et al., 2014).

In the hospitality sector (fast food restaurants inclusive), there exists a varying range of employee workplace behavior within the organization. Some of this behaviour may be constructive actions of employees while others may be destructive actions which may hamper productivity in the work environment. Destructive workplace behaviours has the potential to generate anxiety and stress, cause minor illnesses and in some extreme cases, leads to depression and loss of morale amongst employees (Ashkanasy et al. (2002).

As disastrous as destructive work behaviour can be, it is also know to spread like wildfire amongst the employees which in the long run affects the organizations efficacy, productivity and reputation. Eventually, these negative attitudes take a toll on employees' health and performance which is a recipe for organizational failure and financial losses (Appelbaum et al., 2007).

In the fast food restaurant business, employees' behaviour is a key element in corporate productivity and efficiency as they act as a bridge between the organization and its customers. In addition, it also acts as a catalyst to develop an effective and cordial relationship with customers. Therefore, employees' workplace behavior influences customer perception of service quality which in turn enhances customer satisfaction and organizational efficacy.

In Port Harcourt, the usefulness of fast food restaurants cannot be overemphasized. This is because of its importance in the hospitality sector, tourism and to its numerous customers. Similar to other sectors of the economy, its potential in the long run is significant considering the 
fast growing population of the city, the changing lifestyles as a result of work demands and its economic potential as the hub of oil and other commercial activities in Nigeria.

Prior to this study, many researches have been carried out in this field of endeavour. However, the focus of a plethora of researches was mainly to ascertain work attitudes with little of no emphasis on organization efficacy attributed to employee work attitudes behaviour. Therefore, this study intends to fill this existing lacuna and investigate the relationship between employee attitude and organizational efficacy. In the light of these, the research embarked on this study to explore the relationship between employee work behaviour, motivation and organizational efficacy in the fast food industry

\section{Materials and Methods}

The study was carried out in Port Harcourt, Rivers State.The study implored the use of the descriptive survey research design. The Z-z score mathematical formular for determining infinite population was used to arrive at a sample size of 384 respondents. Well structured questionnaires were distributed to different categories of fast-food restaurant workers who were purposively selected in order to assemble the primary data needed for this study. Face and content validity was achieved by subjecting the questionnaire to review by experts. Cronbach's Alpha reliability coefficient of $\geq 0.7$ was considered reliable for the study. The collected data with the aid of questionnaire was entered into computer software called Statistical Package for Social Science (SPSS version 21.0). It was analyzed using a descriptive statistical analysis and qualitative data was presented on tables with frequency and percentages while inferential analysis was done using simple Statistical technique. The Chi-square statistics which is a non-parametric tool was used to the test the hypotheses.

\section{Results and Discussion}

Table 1 reveals that the total number of male respondents constituted $26.56 \%$ of the total respondents, while the female constituted $73.44 \%$ of the total respondents.In analyzing the characteristics of the respondents by age, $21.88 \%$ were $\leq 25$ years, $50.78 \%$ were between $26-37$ years and $27.34 \%$ were between $37-47$ years. Analysis of data on the educational status of respondents who participated in this study as seen in the table 1 showed that $9.64 \%$ had primary education, $42.45 \%$ had secondary education, $28.13 \%$ respondents had finished a bachelor's degree, $6.51 \%$ had finished postgraduate education, while $13.28 \%$ had vocational educational training. In the analysis of job category, $51.38 \%$ assumed non-supervisory roles, $21.09 \%$ were first-line supervisors, $10.68 \%$ were mid-level managers and $8.85 \%$ were senior managers. 
Table 1: Sociodemographic Data of Respondents

\begin{tabular}{lcc}
\hline Variables & $\begin{array}{c}\text { Frequency } \\
(\mathbf{n}=\mathbf{3 8 4})\end{array}$ & Percent \\
\hline GENDER & & \\
Male & 102 & $26.56 \%$ \\
Female & 282 & $73.44 \%$ \\
AGE & & \\
$\leq 25$ years & 84 & $21.88 \%$ \\
26 - 36years & 195 & $50.78 \%$ \\
37 - 47years & 105 & $27.34 \%$ \\
EDUCATIONAL STATUS & & \\
Primary & 37 & $9.64 \%$ \\
Secondary & 163 & $42.45 \%$ \\
Bachelor's degree & 108 & $28.13 \%$ \\
Post-graduate & 25 & $6.51 \%$ \\
Vocational training & 51 & $13.28 \%$ \\
JOB-CATEGORY & & \\
Non-supervisory & 228 & $51.38 \%$ \\
First line supervisor & 81 & $21.09 \%$ \\
Mid-level manager & 41 & $10.68 \%$ \\
Senior manager & 34 & $8.85 \%$ \\
\hline
\end{tabular}

The distribution of the work experience in the fast food industry is shown in Table 2.It was revealed that238 (61.98\%) had a work experience of up to five years, $115(29.95 \%)$ had six to ten years of work experience while $31(8.07 \%)$ had more than years of work experience.

\section{Table 2: Work Experience of Respondents}

\begin{tabular}{lll}
\hline $\begin{array}{l}\text { Work experience of } \\
\text { respondents }\end{array}$ & $\begin{array}{l}\text { Frequency } \\
(\mathbf{n = 3 8 4})\end{array}$ & Percentage \\
\hline$\leq 5$ years & 238 & $61.98 \%$ \\
$6-10$ years & 115 & $29.95 \%$ \\
$>10$ years & 31 & $8.07 \%$ \\
\hline
\end{tabular}

Figure 1 shows the analysis of the type of employment among respondents. It was revealed that where 151 (39.32\%) had part time employment and 233 (60.68\%) were employed on full-time basis. 


\section{Employment Type of Respondents}

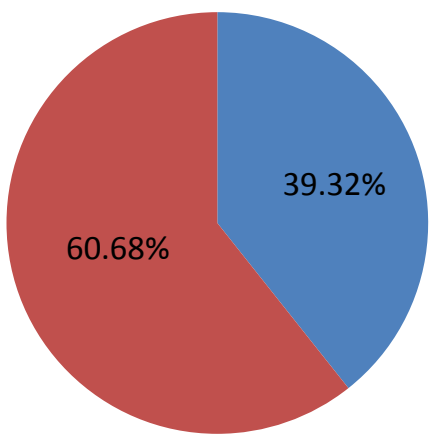

Part-time

Full-time

\section{Figure 1: Employment Type of Respondents}

Figure 2 reveals the rating for organizational performance by the respondents. Results showed that $48(12.5 \%)$ gave a poor rating, $121(31.51 \%)$ gave an average rating and $215(55.99 \%)$ gave a very good rating.

\section{Organizational Performance}

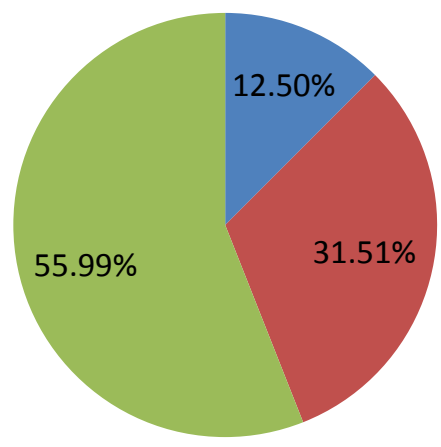

Poor

Average

Very Good

\section{Figure 2: Perception of Organizational Performance}

Figure 3 outlines the perception of organizational efficacy rating by the respondents. Results showed that $36(9.38 \%)$ gave a poor rating, $89(23.18 \%)$ gave an average rating and 259 $(67.45 \%)$ gave a 'very good' rating as shown in the figure 3 below. 


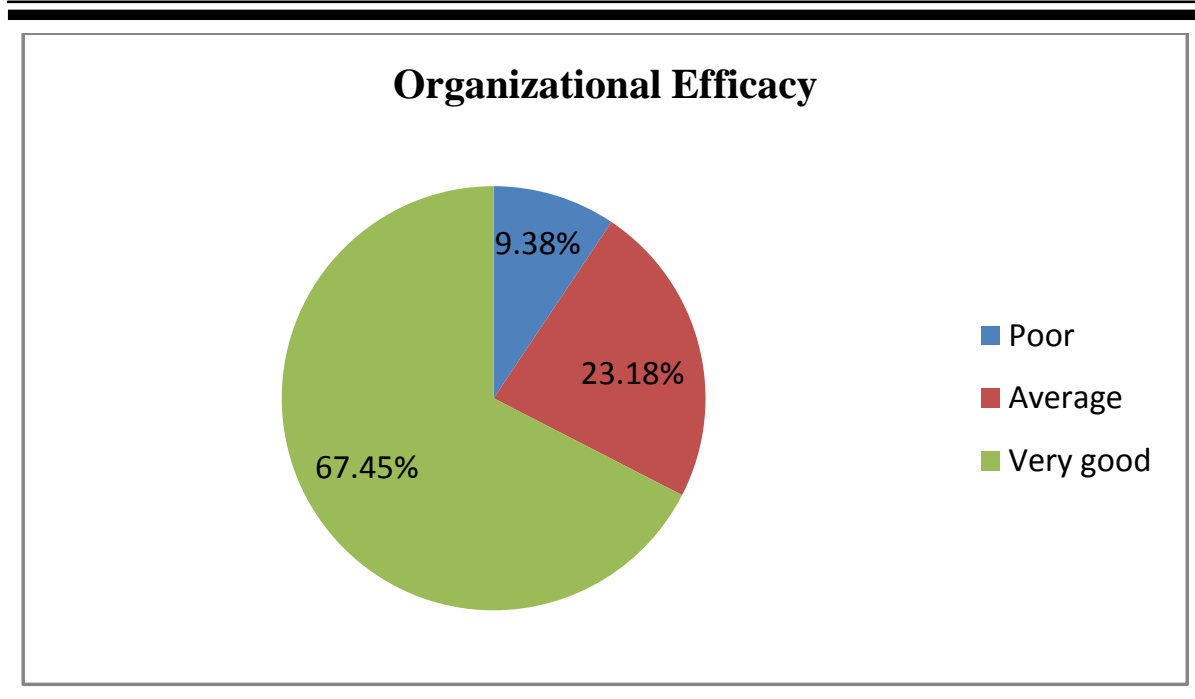

\section{Figure 3: Perception of Organizational Efficacy}

Figure 4 illustrates the job satisfaction rating. Results showed that that $157(40.89 \%)$ were satisfied with their jobs while 227 (59.11\%) were not satisfied with their jobs. This is similar to the findings of Shiraz et al. (2011) which reported that a significant proportion of employees (40 $-65 \%$ ) in fast food restaurant were not satisfied with their jobs.

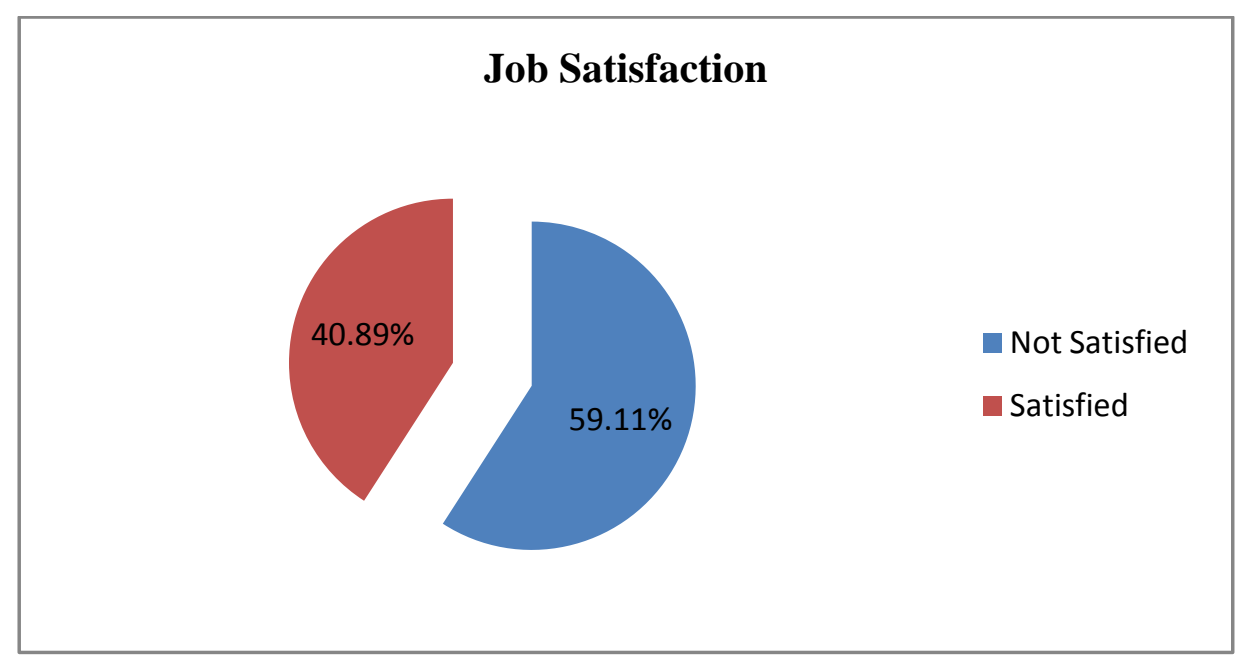

\section{Figure 4: Perception of Job Satisfaction}

Fig 5 clearly illustrates theperception of organizational motivational rating. Results show that 64 $(16.67 \%)$ opined that the organizational motivational rating was poor, 232(60.42\%) was of the opinion that the organizational motivational rating was on the average while $88(22.92 \%)$ had 'very good' motivation. 


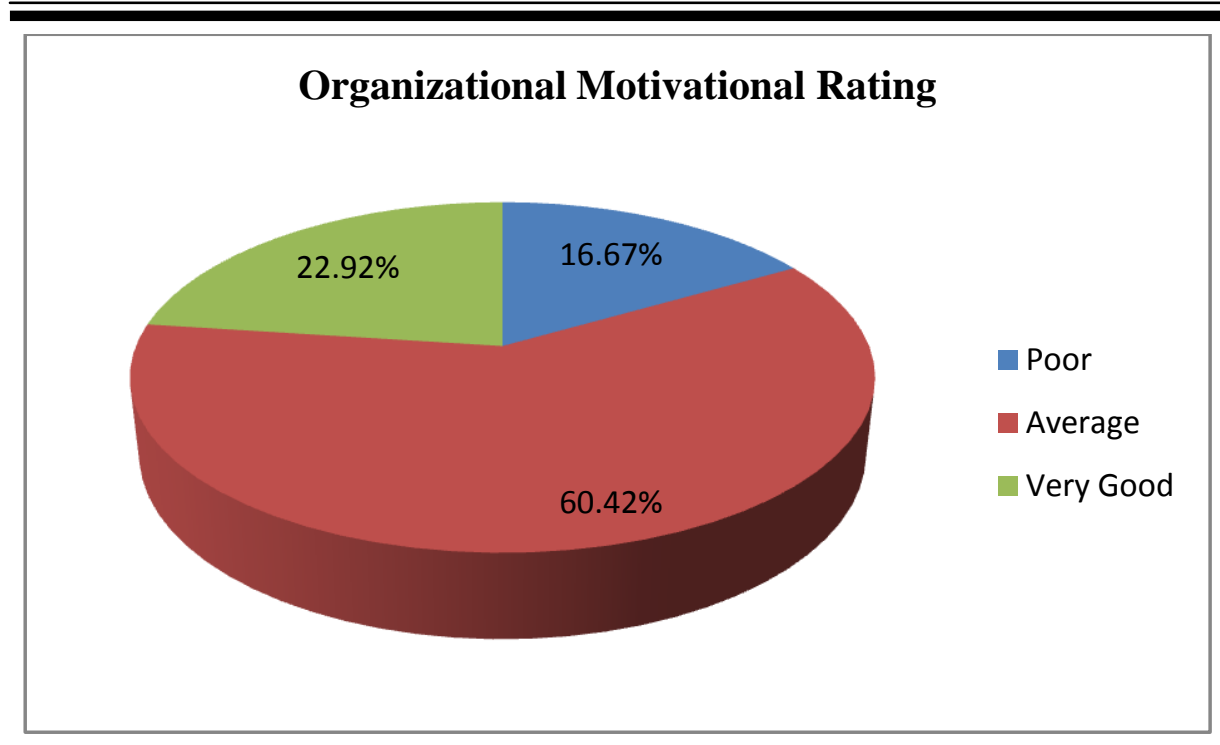

\section{Figure 5: Perception of Organizational Motivational Rating}

Table 3 reveals the chi-square analysis of relationship between organizational performance and adherence to rules. As shown in table 3, the p-value of the chi-square analysis showed a value of 0.000 which implies a statistically significant relationship between organizational performance and adherence to rules. This is similar to the findings of Kura et al. (2013) which reported that adherence to set rules and regulations in an organization improve organizational performance. Similarly, Wang and Duan (2014) also reported that good behaviour correlates with organizational performance in an organization.

Table 3: Relationship between organizational performance and adherence to rules

\begin{tabular}{|c|c|c|c|c|c|c|c|}
\hline & & & & dherence to 1 & & & Chi-Square \\
\hline & & & Rarely & Most times & Always & Total & (P-value) \\
\hline Organizational & Poor & Count & 3 & 33 & 12 & 48 & \\
\hline Performance & & $\begin{array}{l}\% \text { within Organizational } \\
\text { Performance }\end{array}$ & $6.3 \%$ & $68.8 \%$ & $25.0 \%$ & $100.0 \%$ & \\
\hline & Average & Count & 0 & 0 & 121 & 121 & \\
\hline & & $\begin{array}{l}\% \text { within Organizational } \\
\text { Performance }\end{array}$ & $0.0 \%$ & $0.0 \%$ & $100.0 \%$ & $100.0 \%$ & $\begin{array}{c}278.069 \\
(0.000)\end{array}$ \\
\hline & Very good & Count & 0 & 0 & 215 & 215 & \\
\hline & & $\begin{array}{l}\% \text { within Organizational } \\
\text { Performance }\end{array}$ & $0.0 \%$ & $0.0 \%$ & $100.0 \%$ & $100.0 \%$ & \\
\hline Total & & Count & 3 & 33 & 348 & 384 & \\
\hline & & $\begin{array}{l}\% \text { within Organizational } \\
\text { Performance }\end{array}$ & $0.8 \%$ & $8.6 \%$ & $90.6 \%$ & $100.0 \%$ & \\
\hline
\end{tabular}

Table 4 reveals the chi-square analysis of relationship between organizational performance and punctuality. The chi-square analysis showed a p-value of 0.000 which implies a statistically significant relationship between organizational performance and punctuality. This invariably means that punctuality had a significant effect on organizational performance.This study 
corroborates the findings of Fulmer et al. (2013) and Liao and Rupp (2015) who revealed in their separate study thatprompt attendance to work functions have been reported to contribute immensely to organizational performance in all industries.

Table 4: Relationship between organizational performance and punctuality

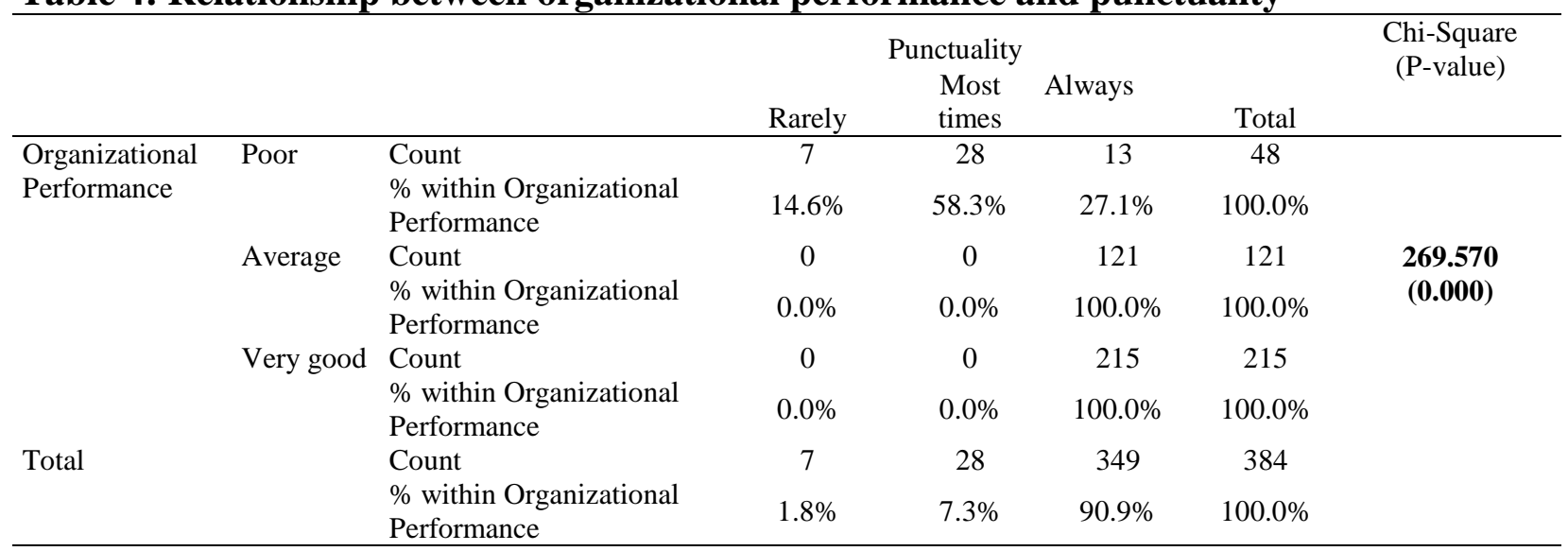

Table 5 reveals the chi-square analysis of relationship between between organizational efficacy and job satisfaction.The chi-square analysis showed a p-value of 0.001 which implies a statistically significant relationship between organizational efficacy and job satisfaction. This invariably means that job satisfaction had a significant effect on organizational efficacy. The findings of this study is in consonance to the findings of Kuntze and Marulich (2010) who reported that job satisfaction corresponds to organizational efficacy.

Table 5: Relationship between organizational efficacy and job satisfaction

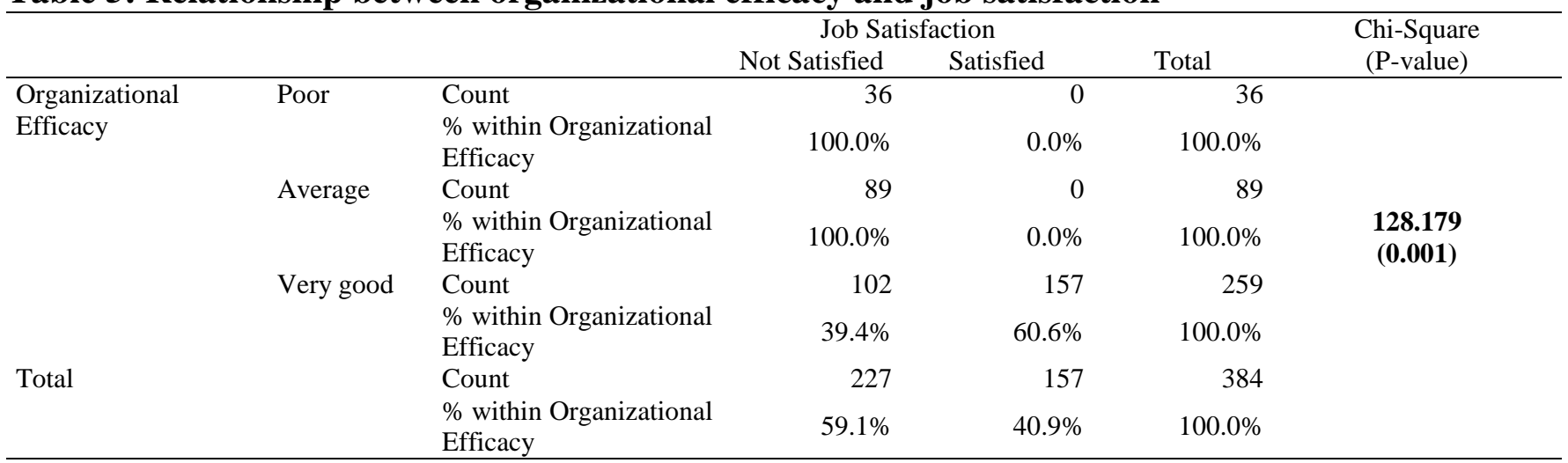

Table 6 reveals the chi-square analysis of relationship between between organizational efficacy and regular work attendance. The chi-square analysis showed a p-value of 0.000 which implies a statistically significant relationship between organizational efficacy and regular work attendance. This invariably means that employees' work attendance had a significant influence on 
organizational efficacy.The findings of this study is in tandem to the findings of Liao and Rupp(2015) who revealed that regular and prompt attendance to work obligations has a significant relationship with organizational efficacy.

Table 6: Relationship between organizational efficacy and work attendance

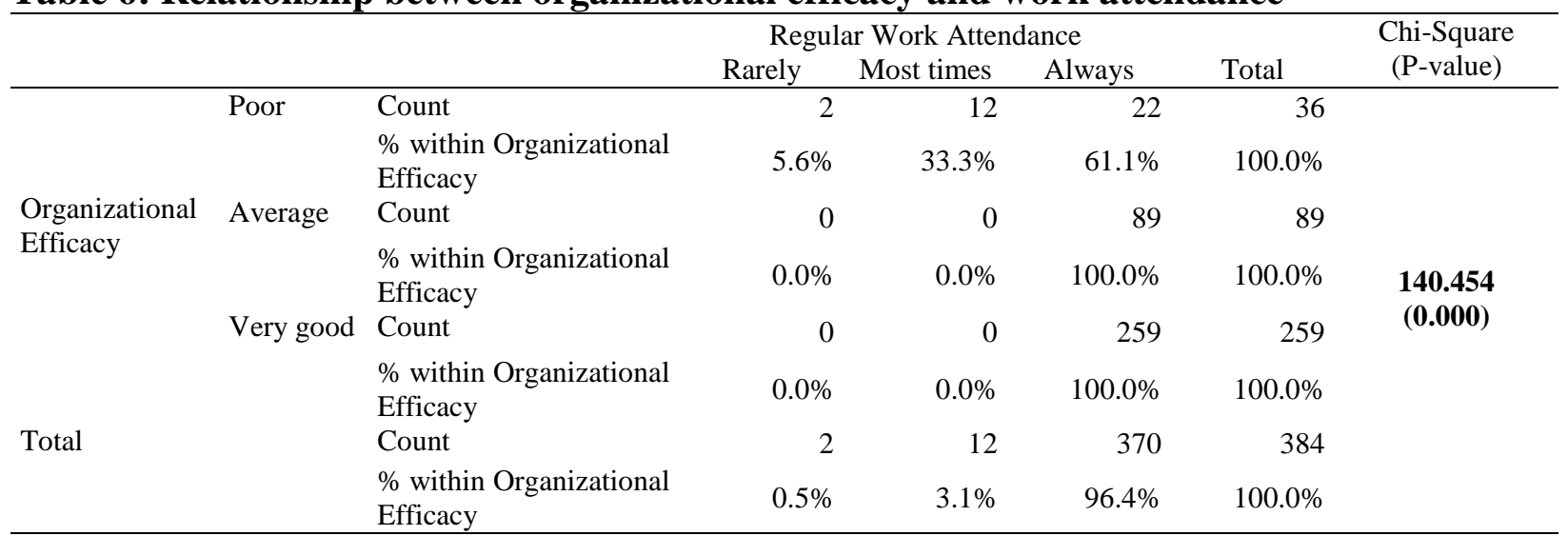

Table 7 reveals the chi-square analysis of relationship between between organizational efficacy and organizational motivational rating. The chi-square analysis showed a p-value of 0.001 which implies that there is a statistically significant relationship between organizational efficacy and organizational motivation rating. This invariably means that employees' motivation had a significant effect on organizational efficacy.This is similar to the findings of Sandhya and Kumar (2011) who revealed that motivation is one of the important factors that improveorganizational performance and efficacy.

Table 7: Relationship between organizational efficacy and motivational rating

\begin{tabular}{|c|c|c|c|c|c|c|c|}
\hline & & & Organizat & al Motivatior & Rating & & Chi-Square \\
\hline & & & Poor & Average & Very good & Total & \\
\hline & Poor & Count & 36 & 0 & 0 & 36 & \\
\hline & & $\begin{array}{l}\% \text { within Organizational } \\
\text { Efficacy }\end{array}$ & $100.0 \%$ & $0.0 \%$ & $0.0 \%$ & $100.0 \%$ & \\
\hline & Average & Count & 28 & 61 & 0 & 89 & \\
\hline $\begin{array}{l}\text { Organizational } \\
\text { Efficacy }\end{array}$ & & $\begin{array}{l}\% \text { within Organizational } \\
\text { Efficacy }\end{array}$ & $31.5 \%$ & $68.5 \%$ & $0.0 \%$ & $100.0 \%$ & 271.394 \\
\hline & Very good & Count & 0 & 171 & 88 & 259 & \\
\hline & & $\begin{array}{l}\% \text { within Organizational } \\
\text { Efficacy }\end{array}$ & $0.0 \%$ & $66.0 \%$ & $34.0 \%$ & $100.0 \%$ & \\
\hline Total & & Count & 64 & 232 & 88 & 384 & \\
\hline & & $\begin{array}{l}\% \text { within Organizational } \\
\text { Efficacy }\end{array}$ & $16.7 \%$ & $60.4 \%$ & $22.9 \%$ & $100.0 \%$ & \\
\hline
\end{tabular}


Table 8 reveals the chi-square analysis of relationship between between organizational efficacy and employee work behaviour. The chi-square analysis showed a p-value of 0.012 which implies a statistically significant relationship between organizational efficacy and employee work behavior. This invariably means that employees' work behaviour had a significant effect on organizational efficacy. This is similar to the findings of Schneider and Bowen(2015) who noted that good employee behaviour has been reported to be associated with increased and improved organizational performance.

Table 8: Relationship between organizational efficacy and employee work behaviour

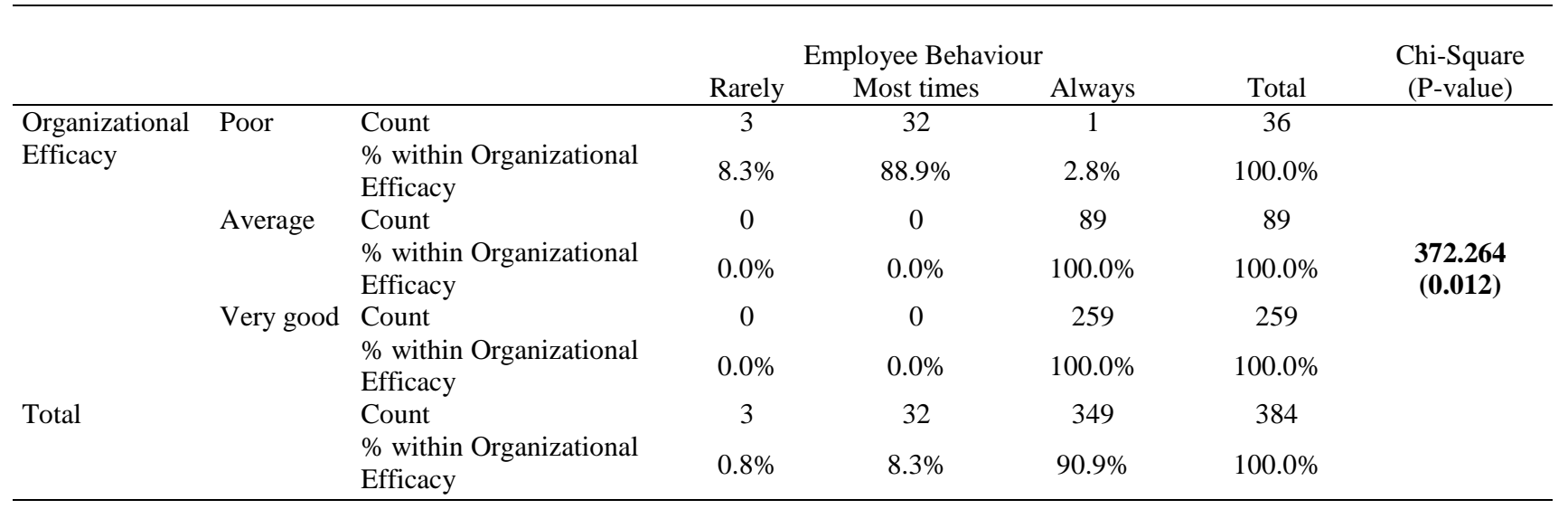

Table 9 reveals the chi-square analysis of relationship between employee work behaviour and gender. The chi-square analysis showed a p-value of 0.571 which implies that the relationship between employee work behaviour and gender was not statistically significant. This means that gender had no significant influence on employee work behaviour.

Table 9: Relationship between employee work behaviour and gender

\begin{tabular}{|c|c|c|c|c|c|c|c|}
\hline & & & & loyee Behav & & & Chi-Square \\
\hline & & & Rarely & Most times & Always & Total & (P-value) \\
\hline Gender & Male & Count & 3 & 32 & 67 & 102 & \\
\hline & & $\%$ within Gender & $2.9 \%$ & $31.4 \%$ & $65.7 \%$ & $100.0 \%$ & 1.120 \\
\hline & Female & Count & 0 & 0 & 282 & 282 & $(0.571)$ \\
\hline & & $\%$ within Gender & $0.0 \%$ & $0.0 \%$ & $100.0 \%$ & $100.0 \%$ & \\
\hline Total & & Count & 3 & 32 & 349 & 384 & \\
\hline & & $\%$ within Gender & $0.8 \%$ & $8.3 \%$ & $90.9 \%$ & $100.0 \%$ & \\
\hline
\end{tabular}




\section{Conclusion and Recommendations}

The study revealed that employee perception of organizational performance and motivational rating was very good. However, a greater percentage of the employees were not satisfied with their jobs. This could be attributed to poor working environment and lack of staff welfare. It was also revealed that employee behaviour such as punctuality, adherence to rules and regular work attendance had significant effect on organizational performance and efficacy. It was also noted that employee motivation was significantly correlated with organizational efficacy.

Based on the findings of the study it is recommended that senior level executives of fast food restaurants in Port Harcourt take a critical appraisal of factors associated with job satisfaction and motivation of employees. Also, it is imperative that employees be adequately encouraged to adhere to rules and regulations, improve on punctuality so as to ensure improvement in organizational efficiency and performance in the fast food restaurants. 


\section{References}

Appelbaum, S.H., Laconi, G.D., \&Matousek, A. (2007). Positive and Negative Deviance Workplace Behaviours: Causes, impacts and solutions. Corporate Governance, 7(5), 586-598.

Ashkanasy, N.M., Zerbe, W.J., \&Hartel, C.E.J. (2002). Managing Emotions in the Workplace. New York: Armonk.

Barney, J. (2011). Firm Resources and Sustained Competitive Advantage.Journal of Management, 17(1), 99-120.

Cascio, W. (2013). Performance Management:Managing Human Resources (5th International Edition) Irwin/McGraw-Hill Publishers.

Fulmer, B., Gerhard, B.,\& Scott, K. (2013). Are the 100 best better? An Empirical Investigation of the Relationship between being a Great Place to Work and Firm Performance. Personnel psychology, 56, 965-993.

Kuntze, R. \&Matulich, E. (2010.) Google: Searching for Value.Journal of Case Research in Business and Economics, 2, 1-10.

Kura, K. M., Shamsudin, F. M., \&Chauhan, A. (2013). Moderating Effect of Self-regulatory Efficacy on the Relationship between Organizational Formal Controls and Workplace Deviance: A proposed framework. International Journal of Academic Research in Business and Social Sciences, 3(1), 15-26.

Liao, H., \& Rupp, D. E. (2015). The Impact of Justice Climate, Climate Strength, and Justice Orientation on Work Outcomes: A multilevel-multifocal framework. Journal of Applied Psychology, 90, 242-256.

Mustapha, A. M., Fakokunde, T. O.,\&Awolusi, O. D. (2014). The Quick Service Restaurant Business in Nigeria: Exploring the Emerging Opportunity for Entrepreneurial Development and Growth.Global Journal and Commerce and Management Perspective, 3(3), 8-14.

Porath, C., \& Pearson, C. (2009). How Toxic Colleagues Corrode Performance. Harvard Business Review, 87 (04).

Sandhya, K., \&Kumar, P.D. (2011). Employee Retention by Motivation. Indian Journal of Science and Technology, 4, 1778-1782.

Schneider, B and Bowen, D.E. (2015). Employee and Customer Perception of Service in Banks: Replication and extension.Journal of Applied Psychology,70, 423-433.

Shiraz, N., Rashid M., \&Riaz, A. (2011). The Impact of Reward and Recognition Programs on Employee's Motivation and Satisfaction.Interdisciplinary Journal of Contemporary Research in Business, 2(3), 1428-1434 
International Journal of Advanced Academic Research (Social and Management Sciences) | ISSN: 2488-9849

Vol. 6, Issue 11 (November, 2020) | www.ijaar.org

Journal DOI: 10.46654/ij.24889849

Article DOI: 10.46654/ij.24889849.s6121011

Wang, Y.Y. and Duan, J.Y. (2014). The Influence of Human Resource Practices on Employee Innovative Behavior: The Mediating role of psychological contract breach and the regulating role of communication between leaders and employees. Psychological Science, $1,172-176$.

Yuan, F., \& Woodman, R. W. (2010). Innovative Behavior in the Workplace: The role of performance and image outcome expectations. Academy of Management Journal, 53(2), $323-342$. 